\title{
Meningkatkan Hasil Belajar Matematika Materi Operasi Hitung Bilangan Bulat Melalui Metode Pembelajaran Kooperatif Tipe Jigsaw Siswa Kelas V SDN Penedapa Kecamatan Poso Pesisir Kabupaten Poso Propensi Sulawesi Tengah
}

\author{
Manawia H Lapase \\ Guru SDN 1 Penedapa, Sulawesi Tengah
}

\begin{abstract}
Abstrak. PTK ini bertujuan untuk meningkatkan hasil belajar mata pelajaran Matematika materi Operasi Hitung Bilangan Bulat Melalui Metode Pembelajaran Kooperatif Tipe. sedangkan manfaatnya untuk mendapatkan teori- teori baru untuk menjadi refleksi penelitian selanjutnya . Kajian ini menggunakan metode PTK yang dilaksanakan dalam dua siklus dan setiap siklus dilaksanakan 2x pembelajaran. Sebagai subjek dalam PTK ini adalah siswa kelas V semester I. Sumber data yang diperoleh dalam PTK ini hasil dari siswa kelas V, hasil observasi oleh teman sejawat dan dokumentasi siswa - siswi . Pengumpulan data diperoleh dengan melaksanakan penilaian pada akhir pembelajaran dan pelaksanaan obsevasi terhadap kegiatan guru dan siswa dalam pembelajaran Sebagai alat pengumpulan data digunakan soal tes, lembar obsevasi dan dokumentasi nilai siswa. Data difentalasi dan divalidasikan dari nilai siswa secara kontilatif hasil dari tersebut hasil belajar mereka kumpulkan dalam daftar nilai . Hasil nilai siswa pada masingmasing tatap muka pembelajaran. Data yang telah diverlidasi dianalisis dengan mencari keberhasilan dan kegiatan pembelajaran dengan mencari NTT-N-TR dari pada belajar siswa. PTK ini merupakan dalam dua siklus setiap siklus dilalsanakan dalam 4 tahap. Perencanaan, Pelaksanaan, Observasi, Refleksi. Hasil yang dicapai dalam penelitian ini ketuntasan belajar pertatap muka pertama 50 persen. Siswa belajar pada tatap muka dua 65 persen siswa tuntas mencapai KKM Dengan demikian rata - rata siswa mencapai ketuntasan, siklus 1 Sedangkan siswa pada siklus ke dua siswa ketuntasan mencapai Dengan demikian dalam siklus kedua rata- rata $71+78,75 / 2=149,75=74,88 \%$
\end{abstract}

Kata kunci: Kooperatif Tipe Jigsaw, Meningkat Hasil Belajar

\section{PENDAHULUAN}

\section{Latar Belakang Masalah}

Peningkatan hasil belajar khususnya pelajaran Matematika di SDN Penedapa belum terlaksana dengan baik guru dalam melaksanakan pembelajaran masih sangat konvesional.Guru melaksanakan pembelajaran belum sesuai dengan yang diharapakan .Hasil belajar yang dicapai masih rendah,hasil belajar ditandai pada jumlah siswa yang mencapai ketuntasan belajar belum mencapai nilai KKM

Guru mengajar masih menggunakan metode ceramah ,sehingga banyak siswa yang membosankan dalam belajar.Pembelajaran seperti ini siswa menjadi bosan sehingga nilai ketentasan sangat rendah. Menurut hasil pengamatan penulis nilai mata pelajaran Matematika materi Operasi hitung Bilangan Bulat dikelas V, siswa memperoleh nilai $50 \%$. Penelitian ini dilaksanakan oleh penulis untuk meningkatkan hasil belajar siswa pada mata pelajaran matematika di kelas V SDN Penedapa Kec Poso Pesisir Kabupaten Poso.

Peningkatan hasil belajar yang ingin dicapai dari $50 \%$ yang tuntas menjadi $70 \%$ .Dari kegiatan penelitian tindakan kelas ini secara bertahap belajar siswa meningkat pada pembelajaran tersebut.Disamping meingkatkan ketuntasan siswa belajar diharapkan ketentasan dari nilai rata-rata .Sehingga dengan kegiatan penelitian ini secara bertahap. Rendahnya hasil belajar pelajaran Matematika pada Kompetensi Dasar materi Operasi hitung Bilangan bulat melalui metode pembelajaran tipe Jigsaw dan hasil belajar yang meningkat. Untuk mengatasi permasalahan tersebut di atas penulis melaksanakan penelitian tindakan kelas. Penulis dengan memperdayakan siswa dengan menggunakan variable masing-masing, sehingga dengan pelaksanaan kegiatan ini 
proses belajar mengajar dapat meningkat. Berdasarkan latar belakang di atas penulis dapat mengidentifiksikan maslah sebagai berikut :

1. Guru dalam melaksanakan pembelajaran sangat menonton

2. Guru belum menggunakan media atau alat peraga yang menunjang

3. Pembelajaran belum menyenangkan

4. Guru belum menggunakan bahan ajar yang sesuai untuk mencapai ketuntasan belajar

5. Guru belum menggunakan pemblajaran kooperatif model learning togerher dengan baik dan benar

\section{Perumusan Masalah}

Berdasarkan latar belakang di atas penulis merumuskan masalah sebagai berkut:

Apakah melalui metode Pembelajaran tipe Jigsaw dapat meningkatkan hasil belajar matematika materi Operasi hitung bilangan bulat siswa kelas V SDN Penedapa Kec Poso Pesisir tahun ajaran 2018/2019 ?

1. Apakah dengan penggunaan metode pembelajaran model tipe jigsaw dapat meningkatkan motivasi dan aktivitas siswa untuk meningkatkan hasil belajarnya?

\section{KAJIAN TEORI}

\section{Pembelajaran Matematika}

Matematika merupakan suatu bahan kajian yang memiliki obyek abstrak dan dibangun melalui proses penalaran deduktif, yaitu kebenaran suatu konsep diperoleh sebagai akibat logis dari kebenaran sebelumnya sehingga keterkaitan dalam matematika bersifat sangat kuat dan jelas (Dinas Pendidikan Kabupaten Sidoarjo, 2005).

Matematika berfungsi untuk mengembangkan kemampuan bernalar melalui kegiatan penyelidikan, eksplorasi, dan eksperimen, sebagai alat pemecahan masalah melalui pola pikir dan model matematika, serta sebagai alat komunikasi melalui simbol, tabel, grafik, diagram, dalam menjelaskan gagasan (Dinas Pendidikan Kabupaten Poso, 2012). Pembelajaran Matematika bertujuan melatih cara berfikir dan bernalar, mengembangkan aktivitas kreatif, mengembangkan kemampuan memecahkan masalah, dan mengembangkan kemampuan menyampaikan informasi dan mengkomunikasikan gagasan (Mohamad Nur, $2007: 32$ )

Penilaian yang dilakukan lebih berfokus pada penilaian berbasiskelas. Dalam merancang penilaian, termasuk memilih teknik dan alat penilaian yang digunakan adalah penilaian tertulis, penilaian kinerja, dan penilaian karya atau portofolio.Standar Kompetensi dirancang secara berdiversivikasi, untuk melayani semua kelompok siswa (normal, sedang, tinggi). Kelompok normal adalah kelompok yang memerlukan waktu belajar relatif lebih lama dari kelompok sedang, sehingga perlu diberikan pelayanan dalam bentuk menambah waktu belajar atau memberikan remediasi. Sedangkan kelompok tinggi adalah kelompok yang memiliki kecepatan belajar lebih cepat dari kelompok sedang, sehingga guru dapat memberikan pelayanan dalam bentuk akselerasi (percepatan) belajar atau memberikan materi pengayaan (Mohamad Nur, 2007: 234 ).

Beberapa aspek penilaian sebagai berikut:

a. Karya meliputi: garis bilangan, maket, model, peta, rumus, dan bangun ruang.

b. Kinerja atau unjuk kerja meliputi: menghitung, menimbang, mengukur jarak, menafsir, mencatat data, dan membuat tabel, grafik, diagram.

c. Perilaku: menunjukkan sifat teliti, menunjukkan sikap kritis, dan kebiasaan berfikir logis (Nur Mohamad, 2007 : 56).

Menurut Dimyati dan Mudjiono, hasil belajar merupakan hal yang dapat dipandang dari dua sisi yaitu sisi siswa dan dari sisi guru.Dari sisi siswa, hasil belajar merupakan tingkat perkembangan mental yang lebih baik bila dibandingkan pada saat sebelum belajar.

Pembelajaran Matematika Realistik (PMR) Sejarah PMR

Pada tahun 1973, Freudenthal memperkenalkan suatu model baru dalam pembelajaran matematika yang akhirnya dikenal dengan nama RME (Realistic Mathematics Education). Dalam penelitian ini RME tersebut diberi istilah sebagai Pembelajaran Matematika Realistik (PMR), 
yang dipandang sebagai pendekatan dan berupa urutan sajian bahan ajar.

PMR awalnya dikembangkan di Negeri Belanda.Pendekatan ini didasarkan pada konsep Freudenthal yang berpendapat bahwa matematika merupakan aktivitas manusia.Dengan ide utamanya adalah bahwa siswa harus diberi kesempatan untuk menemukan kembali (reinvent) ide dan konsep matematika dengan bimbingan orang dewasa (Gravemeijer, 1994).Usaha untuk membangun kembali ide dan konsep matematika tersebut melalui penjelajahan berbagai situasi dan persoalan-persoalan realistik.Realistik dalam pengertian bahwa tidak hanya situasi yang ada di dunia nyata, tetapi juga dengan masalah yang dapat mereka bayangkan (Heuvel, 1998).

Esensi dari Pembelajaran Matematika Realistik (PMR), dapat ditemukan pada pandangan Freudenthal yang sangat penting yang berkaitan dengan PMR yaitu: "mathematics must be connected to reality" dan " mathematics as human activity”. (Waraskamdi.2008) gertian PMR

Dan saat ini pembelajaran masih didominasi oleh guru, siswa kurang dilibatkan sehingga terkesan monoton dan timbul kejenuhan pada siswa. Pembelajaran Matematika Realistik (PMR) adalah suatu teori dalam pendidikan matematika yang dikembangkan pertama kali di negeri Belanda pada tahun 1970 oleh Institut Freudenthal. Matematika realistik yang dimaksudkan dalam hal ini adalah matematika sekolah yang dilaksanakan dengan menempatkan realitas dan pengalaman siswa sebagai titik awal pembelajaran (Gravemeijer: 1994).

Soedjadi (2001: 2) mengemukakan bahwa pembelajaran matematika dengan pendekatan realistik pada dasarnya adalah pemanfaatan realita dan lingkungan yang dipahami peserta untuk memperlancar proses pembelajaran matematika sehingga mencapai tujuan pendidikan matematika secara lebih baik dari pada masa yang lalu.

Realistic mathematics education, yang diterjemahkan sebagai pendidikan matematika realistik (PMR), yaitu sebuah pendekatan belajar matematika yang dikembangkan sejak tahun 1971 oleh sekelompok ahli matematika dari Freudenthal Institute, Utrecht University di Negeri Belanda. 1990) bahwa matematika adalah kegiatan manusia. Menurut pendekatan ini, kelas matematika bukan tempat memindahkan matematika dari guru kepada siswa, melainkan tempat siswa menemukan kembali ide dan konsep matematika melalui eksplorasi masalah-masalah nyata.

1. Pendekatan Mekanistik

Pendekatan mekanistik adalah pendekatan secara tradisional dan didasarkan pada apa yang diketahui dari pengalaman sendiri (diawali dari yang sederhana ke yang lebih kompleks). Dalam pendekatan ini manusia dianggap sebagai mesin. Kedua jenis matematisasi tidak digunakan (Waraskamdi : 2007)

2. Pendekatan Empirik

Merupakan satu pendekatan dimana konsep-konsep matematika tidak diajarkan, dan diharapkan siswa dapat menemukan melalui matematisasi horisontal.

3. Pendekatan Strukturalistik

Merupakan pendekatan yang menggunakan sistem formal, misalnya pengajaran penjumlahan cara panjang perlu didahului dengan nilai tempat, sehingga suatu konsep dicapai melalui matematisasi vertikal.

4. Pendekatan Realistik

Merupakan suatu pendekatan yang menggunakan masalah realistik sebagai pokok permasalahan.

Tujuan PMR yaitu memudahkan siswa dalam menyelesaikan soal cerita yang terkait dengan pecahan bahkan matematika realistik menyajikan materi dengan rill. (scribd.com)

\section{Teori Belajar yang Relevan dengan Perkembangan Matematika Realistik}

\section{Teori piaget}

Piaget (dalam ibrahin, 1999:16) berpandangan bahwa, anak-anak memiliki potensi untuk mengembangkan intelektualnya. Pengembangan intelektual mereka bertolak dari rasa ingin tahu dan memahami dunia disekitarnya. Pemahaman dan penghayatan tentang dunia sekitarnya akan mendorong pikiran merekan untuk menbangun tampilan tentang dunia tersebut 
dalam otaknya. Tampilan yang merupakan struktur mental itu disebut skema atau schemata(jamak).

Piaget menyatakan bahwa prinsip dasar dari pengembangan pengetahuan seseorang adalah berlangsungnya adaptasi pikiran seseorang kedalam realitas disekitarnya.proses adaptasi ini tidak terlepas dari keberadaan skema yang dimiliki orang tersebut serta melibatkan asimilasi, akomodasi dan equiliberation dalam pikirannya.

\section{Teori Vygotsky}

Pandangan Vygotsky (1997) tentang arti penting interaksi social dalam perkembangan intelektual anak tampak dari 4 ide kunci yang membangun teorinya, yaitu:

a. Penekanan pada hakikat sosial.

Vygotsky (1997) mengemukakan bahwa anak belajar melalui interaksi dengan orang dewasa atau teman sebayanya. Dalam proses belajar yang demikian, seorang anak yang sedang belajar tidak hanya menyampaikan pengertiannya atas suatu masalah kepada dirinya sendiri namun ia juga dapat menyampaikan nya pada orang lain disekitarnya.

b. Zone Proximal Development (Wilayah perkembangan terdekat)

Didefinisikan sebagai kemampuan pemecahan masalah di bawah bimbingan orang dewasa atau melalui kerjasama dengan teman sejawat yang lebih mampu. Vygotsky (1997) menjelaskan adanya dua tingkat perkembangan intelektual, yaitu tingkat perkembangan aktual dan tingkat perkembangan potensial. Pada tingkat perkembangan aktual seseorang sudah mampu untuk belajar atau memecahkan masalah dengan menggunakan kemampuan yang ada pada dirinya pada saat itu. Sedangkan tingkat perkembangan potensial adalah tingkat perkembangan intelektual yang dicapai seseorang dengan bantuan orang lain yang lebih mampu.

Tingkat perkembangan potensial terletak diatas tingkat perkembangan aktual seseorang. Perubahan itu berlangsung dengan melalui proses belajar yang terjadi pada wilayah perkembangan terdekat.

\section{c. Pemagangan kognitif (cognitive apprenticheship)}

Menurut Vygotsky (1997), dalam proses pemagangan kognitif seorang siswa bertahap mencapai kepakaran dalam interaksinya dengan seorang pakar, orang dewasa atau teman sebayanya dengan pengetahuan yang lebih.

d. Scaffolding merupakan pemberian sejumlah bantuan kepada siswa selama tahap-tahap awal pembelajaran, kemudian mengurangi bantuan dan memberikan kesempatan untuk mengambil alih tanggung jawab yang semakin besar setelah ia dapat melakukannya (Slavin: 1997). Scaffolding maksudnya seorang guru memberikan bantuan kepada siswanya untuk belajar dan memecahkan masalah. Bantuan tersebut dapat berupa petunjuk, dorongan, peringatan, menguraikan masalah ke dalam langkahlangkah pemecahan, memberikan contoh, dan tindakan-tindakan lain yang memungkinkan siswa itu belajar mandiri.

\section{Teori Ausubel}

Menurut Ausubel (1997) belajar dikatakan bermakna jika informasi yang akan dipelajari siswa disusun sesuai dengan struktur kognitifnya sehingga siswa tersebut mengakaitkan informasi barunya dengan struktur kognitif yang dimilikinya.

\section{Teori Gasong}

Menurut teori Gasong (2009) asimilasi adalah proses kognitif dimana seseorang mengintegrasikan persepsi, konsep ataupun pengalaman baru ke dalam skema atau pola yang sudah ada dalam pikirannya. Asimilasi dipandang sebagai suatu proses kognitif yang menempatkan dan mengklasifikasikan kejadian atau rangsangan baru dalam skema yang telah ada. Proses asimilasi ini berjalan terus. Asimilasi tidak akan menyebabkan perubahan/pergantian skemata melainkan perkembangan skemata.

Menurut Gasong (2009) bahwa Akomodasi, dalam menghadapi rangsangan atau pengalaman baru seseorang tidak dapat mengasimilasikan pengalaman yang baru dengan skemata yang telah dipunyai. Pengalaman yang baru itu bias jadi sama sekali tidak cocok dengan skema yang telah 
ada. Dalam keadaan demikian orang akan mengadakan akomodasi. Akomodasi terjadi untuk membentuk skema baru yang cocok dengan rangsangan yang baru atau memodifikasi skema yang telah ada sehingga cocok dengan rangsangan itu.

\section{Teori Burner}

Burner berpendapat bahwa belajar matematika adalah belajar tentang konsepkonsep dan struktur-struktur serta mencari hubungan antara konsep-konsep dan strukturstruktur tersebut. Menurut Bruner pemahaman atas suatu konsep beserta strukturnya menjadikan materi itu lebih mudah diingan dan dapat dipahami lebih komprehensif. Tiga tahap perkembangan mental menurut Bruner:

\section{a. Enactive}

Dalam tahap ini seseorang mempelajari suatu pengetaahuan secara aktiv dengan menggunakan garis miring memanipulasi benda-benda konkret atau situasi nyata secara langsung.

\section{b. Ikonic}

Pada tahap ini kegiatan belajar seseorang sudah mulai menyangkut mental yang merupakan gambaran dari objek-objek.

\section{c. Simbolic}

Tahap terakhir ini adalah tahap memanipulasi simbol-simbol secara langsung dan tidak lagi terkait dengan objek maupun gambaran objek (Slavin: 1997).

\section{Hasil Belajar}

Secara formal belajar dapat didefinisikan sebagai tingkah laku yang dikaitkan dengan kegiatan sekolah.Belajar merupakan fisik atau badaniah yang hasilnya berupa perubahan-perubahan dalam fisik itu, misalnya, dapat berlari, mengendarai, berjalan, dan sebagainya.Belajar selain merupakan aktivitas fisik juga merupakan kegiatan rohani atau psikhis.

Emerse R. Hilgard dalam bukunya yang dikutip oleh Abu Hanafi "Theories of Learning" mendefinisikan bahwa seorang yang melaksanakan kegiatan belajar maka kelakuannya akan berubah dari sebelumnya. Jadi belajar tidak hanya mengenai bidang intelektual, akan tetapi mengenai seluruh pribadi anak. Seorang dikatakan belajar apabila diasumsikan dalam diri orang tersebut mengalami suatu proses kegiatan belajar yang mengakibatkan suatu perubahan tingkah laku (Wahyudin, 2006:13). Setelah memahami beberapa konsep yang dikemukakan diatas dapat ditarik kesimpulan bahwa belajar merupakan kegiatan psikis dan badaniah yang akan mengubah tingkah laku seseorang yang didapat dari hasil pengalaman dan latihan yang bersifat positif.

Perestasi belajar pada dasarnya adalah hasil yang dicapai dalam usaha penguasaan materi dan ilmu pengetahuan yang merupakan suatu kegiatan menuju terbentuknya kepribadian seutuhnya.Melalui belajar dapat diperoleh hasil yang lebih baik.

Belajar berarti mengubah tingkah laku.Hal ini sejalan dengan yang dikemukakan oleh Sudirman (2008:23) bahwa belajar adalah mengubah tingkah laku. Belajar akan membantu terjadinya suatu perubahan pada diri individu yang belajar. Perubahan itu tidak hanya dikaitkan dengan perubahan ilmu pengetahuan, melainkan juga berbentuk percakapan, keterampilan, sikap, pengertian, harga diri, minat, watak dan penyesuaian diri.Belajar menyangkut segala aspek organisme dan tingkah laku pribadi seseorang, prestasi belajar pada hakekatnya merupakan hasil dari belajar sebagai rangkaian jiwa raga.Psikofisik untuk menuju perkembangan pribadi manusia seutuhnya, yang berarti menyangkut unsur cipta, rasa, dan karsa, ranah kognitif, efektfif dan prestasi motorik.

Prestasi belajar sebagai suatu hasil belajar akan menjangkau tiga ranah atau matra seperti yang dikemukakan oleh Bloom, yaitu matra kognitif, efektif, dan psikomotorik dimana ranah atau matra tersebut dipenuhi menjadi beberapa jangkauan kamampuan. Jangkauan kemampuan tersebut adalah sebagai berikut :

Termasuk kedalam ranah kognitif adalah : (1) pengetahuan dan ingatan (kwoledge), (2) Pemahaman, menjelaskan , meringkas, contoh (comprehension), (3) menguraikan, menentukan hubungan (analysis), (4) mengorganisasikan, merencanakan membentuk bangunan baru (syntesis), (5) menilai (evaluation), dan (6) penerapan (aplication). 
Termasuk kedalam ranah afektif (affective) adalah : (1) sikap menerima (receiving), (2) memberikan respons (responding), (3) menentukan harga (valuing), (4) mengorganisasi (organization), dan (5) memberikan ciri-ciri (characterization).

Ranah psikomotor (psychomotor domain) meliputi: (1) tingkatan mengenal (initiatory levels), (2) tingkatan pra ajeg (preroutine level), dan (3) tingkatan melakukan secara ajeg (routine level) (Sahardiman,1988:25-26).

\section{Model Pembelajaran}

Menurut Joyce (dalam Lince, 2006:13) bahwa model pembelajaran adalah suatu perencanaan atau suatu pola yang digunakan sebagai pedoman dalam merencanakan pembelajaran di kelas atau pembelajaran dalam tutorial dan untuk menentukan perangkat-perangkat pembelajaran.Sedangkan Arends (2007:97) menyatakan bahwa model pembelajaran mengacu kepada pendekatan pembelajaran, lingkungan belajar, dan pengelolaan kelas.

Model pembelajaran dalam penelitian ini diartikan sebagai suatu pola yang digunakan sebagai pedoman dalam merencanakan pembelajaran di kelas.

\section{Model Pembelajaran Kooperatif}

Model pembelajaran kooperatif adalah suatu strategi belajar dimana siswa belajar dalam kelompok kecil saling memiliki tingkat kemampuan berbeda.Menurut Thomson (dalam Lince, 2006:14), pembelajaran kooperatif turut menambah unsur-unsur interaksi sosial pada pembelajaran matematika.Nur (2005:2) mengatakan bahwa model pembelajaran kooperatif menciptakan sebuah revolusi pembelajaran di dalam kelas.Tidak ada lagi sebuah kelas yang sunyi selama pembelajaran. Siswa dapat saling membantu satu sama lain guna menuntaskan bahan ajar akademiknya. Pada pembelajaran kooperatif diajarkan keterampilanketerampilan khusus agar dapat bekerja sama dengan baik di dalamkelompoknya. Contohnya menjadi pendengar yang baik, memberikan penjelasan kepada teman sekelompok dengan baik, siswa diberi lembar kegiatan yang berisi pertanyaan atau tugas yang direncanakan untuk diajarkan.

Model pembelajaran kooperatif mempunyai beberapa tipe, yaitu Student teams Achievement Division (STAD), Jigsaw, Investigasi Kelompok, dan pendekatan structural (Muslimin, 2000:20).

Tabel 1. Perbandingan ke Empat Tipe dalam Model Pembelajaran Kooperatif

\begin{tabular}{|c|c|c|c|c|}
\hline STAD & Jigsaw & Investigas & Kelompok & $\begin{array}{l}\text { Pendekatan } \\
\text { Struktural }\end{array}$ \\
\hline $\begin{array}{l}\text { Tujuan } \\
\text { Kognitif }\end{array}$ & $\begin{array}{l}\text { Informasi akademik } \\
\text { sederhana }\end{array}$ & $\begin{array}{l}\text { Informasi akademik } \\
\text { sederhana }\end{array}$ & \begin{tabular}{|lr} 
Informasi & aka- \\
demik tingkat \\
tinggi \\
keterampilan \\
inkuiri
\end{tabular} & $\begin{array}{l}\text { Informasi } \\
\text { akademik } \\
\text { sederhana }\end{array}$ \\
\hline $\begin{array}{l}\text { Tujuan } \\
\text { Sosial }\end{array}$ & $\begin{array}{l}\text { Kerja kelompok dan } \\
\text { keja sama }\end{array}$ & $\begin{array}{l}\text { Kerja kelompok dan } \\
\text { kerja sama }\end{array}$ & $\begin{array}{lr}\text { Kerjasama } & \text { dalam } \\
\text { kelom } & \text { pok } \\
\text { komplek } & \\
\end{array}$ & \begin{tabular}{|l|} 
Kerempilan \\
kelompok \\
keterampilan \\
sosial
\end{tabular} \\
\hline $\begin{array}{l}\text { Struktur } \\
\text { Tim }\end{array}$ & $\begin{array}{l}\text { Kelompok belajar } \\
\text { heterogen dg } 4-5 \\
\text { orang anggota }\end{array}$ & $\begin{array}{l}\text { Kelompok belajar } \\
\text { heterogen dg } 4-6 \\
\text { orang ang gota } \\
\text { menggu-nakan pola } \\
\text { ke lompok asal dan } \\
\text { kelom-pok ahli }\end{array}$ & $\begin{array}{l}\text { Kelompok belajar } \\
\text { dg } 5-6 \text { anggota } \\
\text { homogen }\end{array}$ & $\begin{array}{l}\text { Bervariasi berdua } \\
\text { bertiga, kelompok } \\
\text { dengan } 4-6 \\
\text { orang anggota }\end{array}$ \\
\hline $\begin{array}{l}\text { Pemilihan } \\
\text { Topik } \\
\text { Pelajaran }\end{array}$ & Biasanya guru & Biasanya guru & Biasanya siswa & Biasanya guru \\
\hline $\begin{array}{l}\text { Tugas } \\
\text { utama }\end{array}$ & $\begin{array}{l}\text { Siswa dapat } \\
\text { menggunakan lembar } \\
\text { kegiatan dan saling } \\
\text { membantu untuk } \\
\text { menuntaskan materi } \\
\text { belajamya. }\end{array}$ & $\begin{array}{lr}\text { Siswa } & \text { mempelajari } \\
\text { mater } & \text { dalam } \\
\text { kelompok } & \text { "ahli" } \\
\text { kemu-dian anggota } \\
\text { kelompok asal } \\
\text { mempe-lajari materi } \\
\text { itu. }\end{array}$ & \begin{tabular}{|l|} 
Siswa \\
menvelesaikan \\
inkuiri kompleks.
\end{tabular} & \begin{tabular}{|l|} 
Siswa \\
mengerjakan \\
tugas-tugas yang \\
diberikan social \\
dan kognitif.
\end{tabular} \\
\hline Penilaian & Tes mingguan & $\begin{array}{l}\text { Bervariasi, dapat } \\
\text { berupa tes mingguan. }\end{array}$ & Menyelesaikan & Bervariasi \\
\hline
\end{tabular}

Model pembelajaran kooperatif adalah suatu strategi belajar dimana siswa belajar dalam kelompok kecil saling memiliki tingkat kemampuan berbeda.Menurut Thomson (dalam Lince, 2006:14), pembelajaran kooperatif turut menambah unsur-unsur interaksi sosial pada pembelajaran matematika.Nur (2007:2) mengatakan bahwa model pembelajaran kooperatif menciptakan sebuah revolusi pembelajaran di dalam kelas.Tidak ada lagi sebuah kelas yang sunyi selama pembelajaran. Siswa dapat saling membantu satu sama lain guna menuntaskan bahan ajar akademiknya. Pada pembelajaran kooperatif diajarkan keterampilanketerampilan khusus agar dapat bekerja sama dengan baik di dalam kelompoknya. Contohnya menjadi pendengar yang baik, memberikan penjelasan kepada teman sekelompok dengan baik, siswa diberi lembar kegiatan yang berisi pertanyaan atau tugas yang direncanakan untuk diajarkan. 
Model pembelajaran kooperatif mempunyai beberapa tipe, yaitu Student teams Achievement Division (STAD), Jigsaw, Investigasi Kelompok, dan pendekatan structural (Muslimin, 2000:20).

\section{Model Pembelajaran Kooperatif Tipe Jigsaw}

Pembelajaran kooperatif tipe Jigsaw adalah satu tipe pembelajaran kooperatif yang terdiri dari beberapa orang anggota dalam satu kelompok yang bertanggungjawab atas penguasaan materi belajar dan mampu mengajarkan bagian tersebut kepada anggota lain dalam kelompoknya (Nur, 2005:63). Banyaknya anggota kelompok dalam pembelajaran kooperatif tipe Jigsaw biasanya terdiri dari $4-6$ orang. Setiap anggota kelompok memiliki tugas masing-masing, dan mereka wajib menjelaskan apa yang ditugaskannya itu kepada kelompok yang lain. Anggota kelompok yang mendapat tugas penguasaan materi itu disebut kelompok ahli.Sedangkan kelompok yang dibentuk pertama kali oleh guru disebut kelompok asal. Jika diilustrasikan akan terlihat seperti gambar berikut. Kelompak Asal

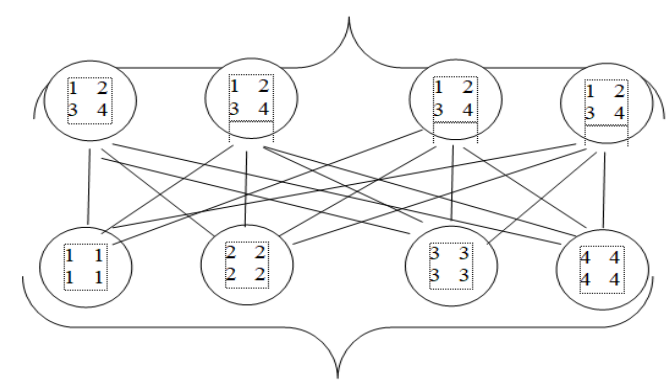

Kelompak Ahli

Keterangan

1 : Materi ke satu

2 : Materi ke dua

3 : Materi ke tiga

4 : Materi ke empat

Kunci keberhasilan Jigsaw adalah saling ketergantungan, yaitu setiap siswa bergantung kepada anggota timnya untuk mendapat informasi yang dibutuhkannya agar dapat mengerjakan kuis dengan baik.

Langkah-langkah pokok pelaksanaan pembelajaran kooperatif tipe Jigsaw adalah pembagian tugas, pemberian lembar ahli, mengadakan diskusi, dan mengadakan kuis.

\section{A. Kerangka berfikir}

Kegiatan penelitian tindakan kelas ini menggunakan metode penelitian tindakan kelas,Penelitian tindakan kelas ini dilaksanakan dalam 2 ( dua) silkus,setiap siklus dilaksanakan 2 ( dua ) kali kegiatan pembelajaran .setiap kegiatan pembelajaran dilaksanakan penilaian

Secara Skematis uraian digambarkan kerangka pemikirannya sebagai berikut:

Gambar 2. Diagram alur Penelitian Tindakan

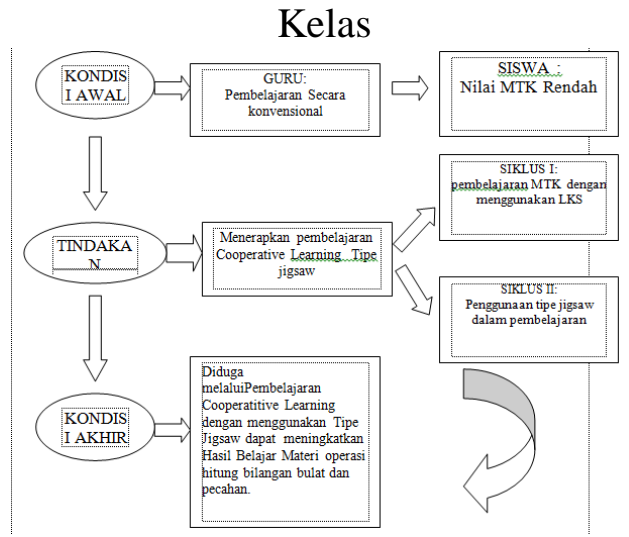

\section{Hipotesis Tindakan}

Pembelajaran Kooperatif Learning Tipe Jigsaw dapat meningkatkan hasil belajar Matematika pada materi operaasi hitung bilangan bulat.

\section{METODOLOGI PENELITIAN}

\section{A. Setting Penelitian}

\section{Tempat Penelitian}

Penelitian Tindakan kelas ini dilaksanakan di SDN Penedapa Kec Poso Pesesir pada mata pelajaran Matematika Tahun Ajaran 2018/2019. Penelitian dilakukan di Kelas V karena peneliti Dasar SK kepala Sekolah diberikan tugas mengajar di kelas V pada sekolah tersebut.

2. Waktu Penelitian

Penelitian ini dilaksanakan selama 3 bulan yaitu pada bulan Agustus s/d November 2019 semester Ganjil Tahun Pelajaran 2018/2019 . Dilakukan pada waktu tersebut karena materi Operasi Hitung Bilangan Bulat merupakan pelajaran yang diajarkan pada semester ganjil.

\section{B. Subyek Penelitian}

Sebagai Subyek penelitian ini adalah siswa-siswi Kelas V tahun pelajaran 2018/ 2019 . Jumlah siswa sebanyak 11 orang terdiri dari 7 laki-laki dan 4 orang siswa 
perempuan umur siswa homogen rata 10 Tahun tingkat kecerdasan yang berbeda-beda

\section{Sumber Data}

Sumber data yang dihimpun dalam penelitian ini adalah :

Siswa-siswa kelas V SDN Penedapa Kec Poso Pesisir tahun ajaran 2018/2019?

1. Teman sejawat sebagai observer yang merupakan kolaborasi dalam pelaksanaan kegiatan penelitian ini

2. Dokumen Penilaian

3. Pihak - pihak lain yang terkait.

D. Teknik dan Alat Pengumpulan Data.

1. Teknik Pegumpulan data dilaksanakn sebagai berikut :

Data yang dikumpulkan dengan cara sebagai berikut :

a. Test.

Test dilakukan pada setiap akhir proses pembelajaran dengan menggunakan instrumen soal (test tulis). Soal yang diberikan adalah soal uraian.

b. observasi

data dari pengamatan yang dilakukan oleh kolaborastor yang dilaksanakan baik pengamatan terhadap kegiatan dalam pembelajaran maupun kegiatan penelitian yang melaksanakan pembelajaran.

c. Wawancara

Data dari wawancara berasal hasil wawancara terhadap pelaksanaan yang terkait

2. Alat Pengumpul Data

Sebagai alat pengumpul data yang digunakan adalah :
a. Butir soal test
b. Lembar instrumen aktivitas siswa
c. Lembar instrumen PBM guru
d. Pedoman wawancara

E. Validasi Data.

1. Nilai Test (hasil belajar).

Tes disusun berdasarkan tujuan pembelajaran yang akan dicapai, digunakan untuk mengukur hasil belajar siswa pada Materi Pengukuran sudut Tes ini diberikan setiap akhir pembelajaran, bentuk tes yang diberikan adalah tes tulisan berbentuk uraian. Validasi diperoleh dari rekaman hasil test siswa.

2. Proses pembelajaran (observasi aktifitas siswa dan Pelaksanan pembelajaran )
Validasi data pada proses pembelajaran ini adalah merupakan triangulasi antara siswa, guru yang melaksanakan PBM dan guru kolaboratif sebagai observer.

\section{F. Analisis Data}

Analisis data yang digunakan adalah analisis deskriptif yang terdiri dari :

1. Hasil belajar, dengan menggunakan analisis deskriptif komparatif

Yaitu dengan mebandingkan nilai test antar kegiatan pembelajaran dan siklus

2. Observasi dengan analisis deskriptif berdasarkan hasil observasi aktifitas siswa dan observasi terhadap pelaksanaan pembelajaran

\section{G. Indikatator Kinerja}

Sebagai indikator keberhasilan yang diharapkan dalam kegiatan penelitian ini adalah:

1. Terjadi peningkatan hasil belajar yaitu dari $50 \%$ menjadi $70 \%$ siswa mencapai ketuntasan belajar.

2. Terjadi peningkatan motivasi belajar siswa pada setiap kegiatan pembelajaran dan antar siklus.

3. Terjadi peningkatan pelaksanaan proses belajar mengajar yang diselenggarakan oleh guru.

4. Penilaian hasil belajar dilaksanakan menggunakan soal tes dalam bentuk pilihan ganda.

\section{H. Prosedur Penelitian.}

Kemmis (dalam wiriaatmadja, Rochiati. 2008:112) menjelas bahwa penelitian Tindakan Kelas adalah sebuah bentuk inkuiri reflektif yang dilakukan secara kemitraan mengenai situasi sosial tertentu (termasuk pendidikan) untuk meningkatkan rasionalitas dan keadilan dari kegiatan praktek sosial, pemahaman suatu kegiatan, dan situasi suatu kegiatan.Rancangan siklus pada penelitian ini dapat meningkatkan hasil belajar matematika pada materi pengukuran sudut melalui metode pembelajaran kooperatif model Tipe Jigsaw siswa kelas V pada SDN Penedapa Kec Poso Pesisir tahun 


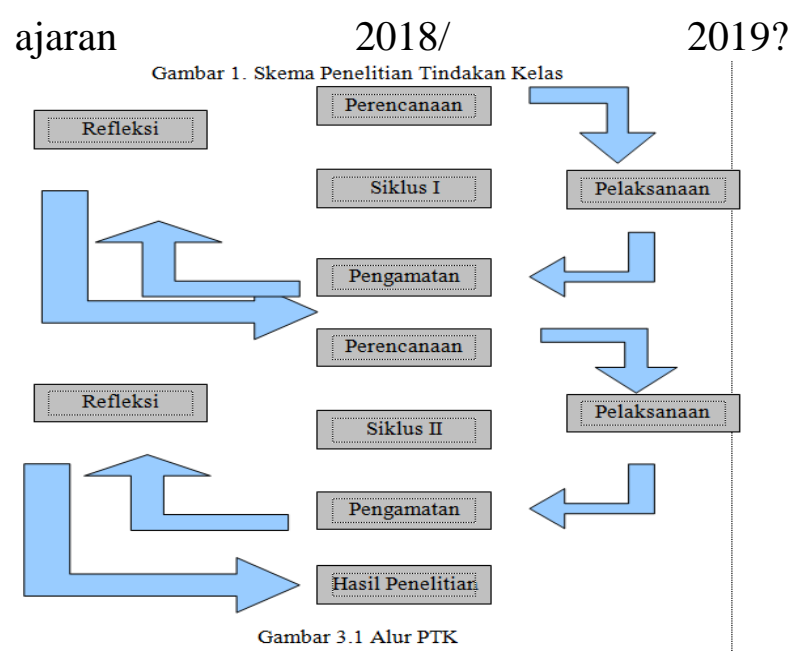

Gambar 3.1 Alur PTK

Penjelasan alur di atas adalah:

1. Rancangan/rencana awal, sebelum mengadakan penelitian peneliti menyusun rumusan masalah, tujuan dan membuat rencana tindakan, termasuk di dalamnya instrumen penelitian dan perangkat pembelajaran.

2. Kegiatan dan pengamatan, meliputi tindakan yang dilakukan oleh peneliti sebagai upaya membangun pemahaman konsep siswa serta mengamati hasil atau dapak dari diterapkannya metode pembelajaran model Tipe Jigsaw

3. Refleksi, peneliti mengkaji, melihat dan mempertimbangkan hasil atau dampak dari tindakan yang dilakukan berdasarkan lembar pengamatan yang diisi oleh pengamat.

4. Rancangan/rencana yang direvisi, berdasarkan hasil refleksi dari pengamat membuat rancangan yang direvisi untuk dilaksanakan pada siklus berikutnya. Observasi dibagi dalam tiga putaran, yaitu putaran 1, 2 dan 3,dan 4 dimana masing putaran dikenai perlakuan yang sama (alur kegiatan yang sama) dan membahas satu sub pokok bahasan yang diakhiri dengan tes formatif di akhir masing putaran. Dibuat dalam tiga putaran dimaksudkan untuk memperbaiki sistem pengajaran yang telah dilaksanakan.

\section{Instrumen Penelitian}

Instrumen yang digunakan dalam penelitian ini terdiri dari:

1. Silabus

Yaitu seperangkat rencana dan pengaturan tentang kegiatan pembelajaran pengelolahan kelas, serta penilaian hasil belajar.

2. Rencana Pelajaran (RPP)

Yaitu merupakan perangkat pembelajaran yang digunakan sebagai pedoman guru dalam mengajar dan disusun untuk tiap putaran.Masingmasing RPP berisi kompetensi dasar, indikator pencapaian hasil belajar, tujuan pembelajaran khusus, dan kegiatan belajar mengajar.

3. Lembar Kegiatan Siswa

Lembar kegitan ini yang dipergunakan siswa untuk membantu proses pengumpulan data hasil kegiatan proses belajar mengajar dengan metode kooperatif model jigsaw .

4. Lembar Observasi Kegiatan Belajar Mengajar

a. Lembar observasi pengolahan metode pembelajaran kooperatif model jigsaw untuk mengamati kemampuan guru dalam mengelola pembelajaran.

b. Lembar observasi aktivitas siswa dan guru, untuk mengamati aktivitas siswa dan guru selama proses pembelajaran.

5. Tes formatif

Tes ini disusun berdasarkan tujuan pembelajaran yang akan dicapai, digunakan untuk mengukur kemampuan pemahaman konsep matematika pada Materi Operasi hitungbbilangan bulatTes formatif ini diberikan setiap akhir putaran. Bentuk soal yang diberikan adalah pilihan ganda (objektif).Sebelumnya soal-soal ini berjumlah 45 soal yang telah diujicoba.

\section{J. Metode Pengumpulan Data}

Data-data yang diperlukan dalam penelitian ini diperoleh melalui observasi pengolahan metode pembelajaran kooperatif model Tipe Jigsawobservasi aktivitas siswa dan guru, dan tes formatif.

\section{K. Teknik Analisis Data}

Untuk mengetahui keefektivan suatu metode dalam kegiatan pembelajaran perlu diadakan analisa data. Pada penelitian ini menggunakan teknik analisis deskriptif kualitatif, yaitu suatu metode penelitian yang 
bersifat menggambarkan kenyataan atau fakta sesuai dengan data yang diperoleh dengan tujuan untuk mengetahui prestasi belajar yang dicapai siswa juga untuk memperoleh respon siswa terhadap kegiatan pembelajaran serta aktivitas siswa selama proses pembelajaran.

Untuk mengalisis tingkat keberhasilan atau persentase keberhasilan siswa setelah proses belajar mengajar setiap putarannya dilakukan dengan cara memberikan evaluasi berupa soal tes tertulis pada setiap akhir putaran.

Analisis ini dihitung dengan menggunakan statistic sederhana yaitu:

1. Untuk menilai ulangan atau tes formatif Peneliti melakukan penjumlahan nilai yang diperoleh siswa, yang selanjutnya dibagi dengan jumlah siswa yang ada di kelas tersebut sehingga diperoleh rata-rata tes formatif dapat dirumuskan:

$$
\bar{X}=\frac{\sum X}{\sum N}
$$

$$
\text { Dengan } \quad \begin{aligned}
: \bar{X} & =\text { Nilai rata-rata } \\
\Sigma X & =\text { Jumlah semua }
\end{aligned}
$$

nilai siswa

\section{Untuk ketuntasan belajar}

$$
\Sigma \mathrm{N}=\text { Jumlah siswa }
$$

Ada dua kategori ketuntasan belajar yaitu secara perorangan dan secara klasikal. Berdasarkan petunjuk pelaksanaan belajar mengajar kurikulum 2006 (Dinas, 2006), yaitu seorang siswa telah tuntas belajar bila telah mencapai skor $65 \%$ atau nilai 65, dan kelas disebut tuntas belajar bila di kelas tersebut terdapat $85 \%$ yang telah mencapai daya serap lebih dari atau sama dengan $65 \%$. Untuk menghitung persentase ketuntasan belajar digunakan rumus sebagai berikut:

$$
P=\frac{\sum \text { Siswa.yang.tuntas.belajar }}{\sum \text { Siswa }} \times 100 \%
$$

1. Untuk lembar observasi

a. Lembar observasi pengelola metode pembelajarn koooperatif model Jigsaw

Untuk menghitung lembar observasi pengelolaan metode pembelajaran kooperatif model Jigsaw rumus sebagai berikut :

$$
\overline{\mathrm{X}}=\frac{P 1+P 2}{2}
$$

Dimana $\mathrm{P} 1=$ Pengamat 1 dan $\mathrm{P} 2=$ Pengamat 2

b. Lembar observasi aktifitas guru dan siswa Untuk menghitung lembar observasi aktifitas guru dan siswa digunakan rumus sebagai berikut :

$$
\begin{aligned}
& \%=\frac{\bar{x}}{\sum x} \times 100 \% \text { den } \\
& \overline{\mathrm{x}}=\frac{\text { Jumahhasil.pe }}{\text { Jumlah.pen }} \\
& \frac{P 1+P 2}{\partial} \\
& : \%=\text { Presentas } \\
& =\text { Rata-rata } \\
& =\text { Jumlah rata-rata } \\
& \text { Pengamat } 1
\end{aligned}
$$$$
\mathrm{P} 1 \text { = Pengamat } 1
$$$$
\mathrm{P} 2 \text { = Pengamat } 2
$$

\section{HASIL PENELITIAN DAN PEMBAHASAN}

\section{A. Hasil Penelitian}

Deskrepsi kondisi awal

Guru mengajar masih menggunakan metode ceramah ,sehingga banyak siswa yang membosankan dalam belajar.Pembelajaran seperti ini siswa menjadi bosan sehingga nilai ketentasan sangat rendah

Menurut hasil pengamatan penulis nilai mata pelajaran Matematika materi Operasi hitung Bilangan Bulat dikelas V, siswa memperoleh nilai $50 \%$

Penelitian ini dilaksanakan oleh penulis untuk meningkatkan hasil belajar siswa pada mata pelajaran matematika di kelas V SDN Penedapa Kec Poso Pesisir tahun ajaran 2018/ 2019 ?

Peningkatan hasil belajar yang ingin dicapai dari $50 \%$ yang tuntas menjadi $70 \%$.

\section{Hasil Penelitian}

\section{a. Siklus I}

1) Perencanaan

Tahap perencanaan pada siklus I dihasilkan beberapa perangkat pembelajaran dan instrumen penelitian.Perangkat pembelajaran yang dihasilkan adalah Rencana Pembelajaran (RPP), Buku Siswa (merupakan kumpulan lembar ahli), Buku Guru, dan Lembar Kegiatan Siswa (LKS).Adapun materi yang dibahas dalam perangkat pembelajaran tersebut adalah pokok bahasan 
Bilangan Bulat, yang meliputi operasi penjumlahan, pengurangan, perkalian, pembagian, serta menaksir hasil perkalian dan pembagian.

Langkah-langkah pembelajaran yang disusun dalam RPP didesain sesuai dengan langkah-langkah pada model pembelajaran kooperatif tipe Jigsaw.Buku siswa yang disusun merupakan kumpulan lembar ahli berupa uraian materi dari topic-topik yang dibahas. Sedangkan buku guru merupakan panduan bagi guru selama proses pembelajaran. Buku ini memuat buku siswa yang dilengkapi beberapa penjelasan.

Sebelum uji coba dilaksanakan, pada bagian akhir buku siswa/lembar ahli diberikan beberapa soal latihan.Karena sebagian besar siswa lebih memperhatikan soal daripada uraian materi, maka pada tatap muka berikutnya soal latihan yang ada di buku siswa/lembar ahli dihilangkan.

Ada beberapa kelemahan yang terjadi saat penyusunan perangkat pembelajaran, yaitu pada tahap validasi.Karena guru matematika SDN Penedapa Kec Poso Pesisir guru kelas.

Sedangkan instrumen penelitian yang dihasilkan adalah lembar pengamatan aktivitas siswa, lembar pengamatan aktivitas guru, serta angket respon siswa.

2) Pelaksanaan dan Observasi

Tahap ini merupakan pelaksanaan dari RPP yang sudah didesain mengikuti model pembelajaran kooperatif tipe Jigsaw.Berikut ini salah satu contoh pelaksanaan pembelajaran di kelas.

\section{a Pertemuan Pertama}

\section{(1) Pendahuluan (10 menit)}

- Guru memulai pelajaran mengacu pada apa yang telah dikenal siswa tentang bilangan bulat, yaitu dengan cara meminta siswa untuk menyebutkan beberapa contoh bilangan bulat. Sebagian besar siswa dapat menjawab pertanyaan guru, tetapi secara bersama-sama.Sedangkan siswa yang berani mengemukakan pendapat sendiri hanya dua orang.

- Guru menyampaikan garis besar tujuan pembelajaran hari itu, yaitu akan membahas beberapa operasi pada bilangan bulat.
3) Kegiatan Inti (60 menit)

- Guru menyampaikan suatu masalah dan menginformasikan bahwa masalah ini dapat diselesaikan dengan berbagai cara dan meminta siswa untuk menyelesaikannya. Siswa yang berani mengemukakan pendapatnya satu orang.

- Guru mengorganisasikan siswa ke dalam kelompok-kelompok heterogen beranggotakan 5 orang, dan meminta siswa untuk duduk sesuai kelompoknya. Kelompok tersebut dinamakan kelompok asal.Kemampuan guru dalam mengorganisasikan siswa masih perlu perbaikan.

- Guru memberikan topik-topik yang akan dibahas pada setiap kelompok, yaitu tentang penjumlahan, pengurangan, perkalian, pembagian, serta menaksir hasil perkalian dan pembagian pada bilangan bulat. Setiap anggota kelompok mendapat tugas satu topik.

- Guru meminta siswa agar anggota kelompok yang menerima tugas yang sama membentuk kelompok baru, selanjutnya disebut kelompok ahli.

- Guru memberikan lembar ahli sesuai dengan tugas yang diterima.

- Siswa membaca dan mempelajari topik ahli dengan waktu \pm 10 menit. Pada kesempatan ini ada beberapa siswa yang bertanya kepada guru Meksi.Mereka lebih senang bertanya kepada gurunya daripada berdiskusi dengan anggota kelompok.

- Guru meminta siswa mendiskusikan topik yang sama dalam kelompok ahli \pm 15 menit, serta mengingatkan bahwa setiap siswa harus benar-benar memahami topik yang ditugaskan tersebut, karena mereka harus menjelaskan apa yang mereka diskusikan kepada temannya di kelompok asal. Pada diskusi itu siswa dapat bertanya, mengemukakan pendapat, interupsi, memberi saran, membuat kesimpulan, menulis dan sebagainya.(Ternyata pada pertemuan pertama ini siswa tidak melakukan diskusi.Mereka asyik membaca lembar ahli sendiri-sendiri.Bahkan ada diantara mereka yang melakukan perilaku tidak relevan, seperti bercanda, menggoda temannya.Melihat kejadian tersebut $\mathrm{Bu}$ 
Meksi mengingatkan kembali bahwa mereka harus diskusi agar semua anggota kelompoknya mengerti.Selanjutnya guru bertanya "Apakah semua anggota sudah dapat menjelaskan kepada kelompok temannya yang ada di kelompok asal?Mereka menjawab Selanjutnya guru meminta siswa kembali ke kelompok semula.

- Masing-masing ahli kembali ke kelompok asalnya untuk menjelaskan topik yang dibahas di kelompok ahli pada kelompok asalnya \pm 10 menit. Meksi memberikan instruksi bahwa topik yang dibahas pertemuan ini tentangpenjumlahan.Siswa yang mendapat tugas yang lain akan menjelaskan pada pertemuan berikutnya. Selanjutnya guru membimbing kelompok belajar tersebut. Sebagian besar siswa enggan memberikan penjelasan kepada temannya.Guru harus jeli memintaagar siswa yang mendapat tugas penjumlahan segera menjelaskan kepada anggota kelompoknya. Tetapi tampaknya mereka masih ragu.Mereka belum percaya diri, karena selama ini yang menerangkan materi selalu guru.

- Guru memberikan LKS-1, dan meminta siswa untuk mengerjakan LKS tersebut selama 15 menit.

4) Penutup (10 menit)

- Bersama dengan siswa, guru membahas hasil kerja siswa dan dilanjutkan dengan menghitung skor yang diperoleh tiap kelompok.

- Memberikan penghargaan kepada kelompok yang mendapat skor paling tinggi, dan kepada siswa yang paling berpartisipasi.

- Membuat rangkuman tentang pembelajaran hari itu, yaitu penjumlahan pada bilangan bulat beserta sifat-sifatnya. Waktu menyimpulkan hasil pembelajaran ada beberapa siswa yang berani menyimpulkan beberapa sifat pembulatan penjumlahan.

- Menginformasikan materi yang akan dibahas pada pertemuan berikutnya, yaitu tentang pengurangan pada bilangan bulat.

\section{b Pertemuan Kedua}

(1) Pendahuluan (10 menit)

- Guru menyampaikan garis besar tujuan pembelajaran hari itu, yaitu akan membahas masalah operasi pengurangan pada bilangan bulat. Siswa menyimak penjelasan guru.

- Dengan tanya jawab guru mengingatkan kembali tentang sifat-sifat pada penjumlahan bilangan bulat. Beberapa siswa sudah mau berpartisipasi menjawab pertanyaan guru.

(2) Kegiatan Inti (45 menit)

- Guru meminta siswa agar duduk berkelompok seperti sebelumnya, yaitu kelompok asal.

- Guru meminta siswa yang mendapat topik pengurangan dan perkalian pada bilangan bulat untuk menjelaskan kepada kelompoknya tentang materi itu masingmasing selama \pm 10 menit. Pada pertemuan ke dua ini siswa sudah mulai berani memberikan penjelasan kepada temannya, tetapi tetap harus disuruh oleh guru dan didampingi.Gurumembimbing siswa yang bertugas untuk memberikan penjelasan. Tetapi jika yang bersangkutan belum bersedia,Guru meminta anggota yang lain untuk memberikan penjelasan. Setelah waktu untuk diskusi habis, guru membagikan LKS untuk mengetahui pemahaman siswa terhadap materi yang telah dibahas kelompok.

- Guru membagikan LKS-2 dan LKS-3 serta meminta seluruh siswa untuk mengerjakannya selama 25 menit dan tidak boleh bekerja sama. Siswa mengerjakan $L K S$ dengan antusias, bahkan ada siswa yang mengerjakannya sambil nyanyinyanyi, sehingga temannya merasa terganggu.

(3) Penutup (10 menit)

- Bersama dengan siswa, guru membahas hasil kerja siswa yaitu LKS-2 dan LKS-3 dilanjutkan dengan menghitung skor perkembangan.

- Memberikan penghargaan kepada kelompok yang mendapat skor paling tinggi, dan kepada siswa yang paling berpartisipasi.

- Membuat rangkuman tentang pembelajaran hari itu, yaitu pengurangan dan perkalian bilangan bulat beserta sifat-sifatnya. Pada kesempatan ini ada beberapa siswa yang berani memberi simpulan sifat-sifat pengurangan dan perkalian pada bilangan bulat. 
- Menginformasikan materi yang akan dibahas pada pertemuan berikutnya, yaitu masalah pembagian pada bilangan bulat.

Selama pembelajaran berlangsung dilakukan pengamatan terhadap aktivitas siswa dan guru. Aktivitas siswa dikelompokkan menjadi dua kelompok seperti pada tabel berikut

Tabel 3 Pengelompokan Aktivitas Siswa

\begin{tabular}{|c|c|}
\hline Kelompok & Kode Aktivitas \\
\hline Partisipasi Aktif & $1,3,4,5,6$ \\
\hline Partisipasi Pasif & 7,8 \\
\hline
\end{tabular}

Siklus I ini terdiri dari empat tatap muka.Pada tatap muka yang keempat siswa diminta untuk mengisi angket yang memuat respon siswa terhadap kegiatan pembelajaran yang sudah dilaksanakan. Karena jumlah siswa di kelas cukup banyak, sedangkan guru matematika di SDN Penedapa Kec Poso Pesisir

2 orang teman sejawat mengamati aktivitas siswa peneliti. Hasil pengamatan dari keempat pertemuan tersebut diperoleh data sebagai berikut.

Data Aktivitas Siswa

\begin{tabular}{|c|c|c|c|c|c|}
\hline \multirow{2}{*}{$\begin{array}{l}\text { Tabel } 4 \text { Frekuensi Rata-rata (\%) Aktivitas Siswa Tiap } \\
\text { Kategori Pada Siklus I Kategori } \\
\text { Pengamatan }\end{array}$} & \multicolumn{4}{|c|}{$\begin{array}{l}\text { Frekuensi Rata-rata (\%) Pertemuan } \\
\text { ke }\end{array}$} & \multirow{2}{*}{$\begin{array}{c}\begin{array}{c}\text { Rata- } \\
\text { rata }\end{array} \\
(\%) \\
\end{array}$} \\
\hline & I & II & III & IV & \\
\hline 1 & 62,875 & 66,875 & 66,25 & 75 & 67,75 \\
\hline 2 & 37.059 & 37.059 & 40.714 & 32.059 & 36.7227 \\
\hline 3 & 1.029 & 0.441 & \begin{tabular}{|l|}
1.286 \\
\end{tabular} & 1.324 & 1.0199 \\
\hline 4 & 0 & 0 & \begin{tabular}{|l|}
0.571 \\
\end{tabular} & 0.588 & 0.2899 \\
\hline 5 & 0.294 & 1.324 & \begin{tabular}{|l|l}
1.714 \\
\end{tabular} & 1.618 & 1.2374 \\
\hline 6 & 22.206 & 19.853 & 22 & 20.294 & 21.0882 \\
\hline 7 & 10.294 & 16.471 & 13.286 & 13.529 & 13.3949 \\
\hline 8 & 0.588 & 0.735 & \begin{tabular}{|l|}
0.857 \\
\end{tabular} & 0.441 & 0.6555 \\
\hline 9 & 15.735 & 8.382 & 5.429 & 6.324 & 8.9674 \\
\hline 10 & 4,56 & 5,86 & 6,67 & 6,90 & 5,9975 \\
\hline 11 & 5,57 & 6,05 & 6,70 & 8,80 & 6,78 \\
\hline
\end{tabular}

Frekuensi rata-rata aktivitas siswa yang termasuk kategori aktif sebesar $67,75 \%$ a. Data Aktivitas Guru

Aktivitas guru pada siklus I ini menunjukkan perkembangan yang sangat baik.Pada pertemuan ke-1 guru mengalami kesulitan dalam mengorganisasikan siswa. Selain itu saat membimbing siswa selama belajar kelompok, guru cenderung memberikan jawaban langsung, tanpa mengalihkan pertanyaan itu ke anggota kelompok yang lain. Namun pada tatap muka berikutnya aktivitas guru tersebut sudah lebih baik.Secara keseluruhan perkembangan aktivitas guru dapat dilihat pada tabel berikut.

Tabel 5. Perkembangan Tingkat Kinerja Aktivitas Guru pada siklus I

\begin{tabular}{|c|l|l|l|l|l|l|l|l|l|}
\multirow{2}{*}{ No } & \multirow{3}{*}{ Nama siswa } & \multicolumn{4}{|c|}{ Pertemuan } & \multicolumn{5}{c|}{ Pertemuan } \\
\hline & & \multicolumn{3}{|c|}{ I } & \multicolumn{5}{|c|}{ II } \\
\hline & & BS & L & PP & TPP & BS & L & PP & TPP \\
\hline 1 & Andre Prasetyo & & V & & V & V & & & \\
\hline 2 & Aan Dahlan & & & V & & & & V & \\
\hline 3 & Irwansah & & & V & & & & V & \\
\hline 4 & Moh Irvan & & V & & & & V & & \\
\hline 5 & Moh Rasya & & & V & & & & V & \\
\hline 6 & Moh Riski & & V & & V & & V & & \\
\hline 7 & Nurul Hidayah & & & V & & & V & & \\
\hline 8 & Nura'in & & V & & & & V & & \\
\hline 9 & Nurjanah & & & V & & & & & \\
\hline 10 & Safitri & & V & & & & V & & \\
\hline 11 & Abdul Halik & & & V & & & V & & \\
\hline
\end{tabular}

\section{Keterangan $: \mathrm{BS}=$ Baik}

$\mathrm{L}=$ Layak

$\mathrm{PP}=$ Perlu Perbaikan

TPP $=$ Tidak perlu perb

b. Data Respon Siswa

setelah tahap pelaksanaan selesai,selanjutnya siswa diminta untuk mengisi angket.Tujuan dari pemebrian angket adalah ingin mengetahui respon siswa terhadap pembelajaran yang sudah dilaksanakan.Adapun data yang diperoleh sebagai berikut :

table 6 Respon siswa terhadap kegiatan Pembelajaran Kooperatif Tipe Jigsaw

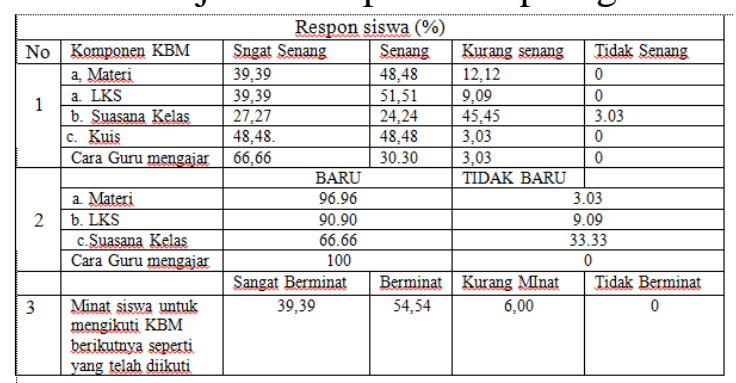

\section{c Repleksi}

Dengan memeprhatikan respon siswa serta hasil pengalaman baik terhadap siswa maupun terhadap guru,diperoleh hal-hal sebagai berikut .

- Prosentase rata-rata aktivitas yang termasuk katagori partisifasi aktif sebesar $54,31 \%$

- Aktivitas ke-5, yaitu kemampuan mengemukakan pendapat perlu ditingkatkan, karena baru mencapai 1,24\%. Begitu juga kemampuan untuk mengambil kesimpulan juga harus ditingkatkan.

- Berdasarkan catatan di lapangan, pada siklus I ini, siswa masih sering mengemukakan pendapat secara serempak, belum berani mengemukakan pendapat sendiri-sendiri. 
- Pada siklus I ini, perilaku yang tidak relevan cukup tinggi, yaitu $8,97 \%$. Menurut pengamatan peneliti, hal ini terjadi karena penelitian dilakukan di semester I, dimana mereka satu sama lain baru saling kenal, bahkan guru pun masih berusaha menghafal nama siswasiswanya.

- Aktivitas guru dari pertemuan satu ke pertemuan berikutnya makin membaik. Kami selalu memberikan masukan kepada guru setiap selesai mengajar.

- Karena respon siswa terhadap KBM sangat baik, maka perangkat pembelajaran dan instrumen pada siklus II desainnya tetap seperti pada siklus I.

- Untuk meningkatkan kemampuan siswa dalam mengemukakan pendapat, mengambil kesimpulan, memberi saran, keberanian untuk bertanya, maka langkah pembelajaran pada siklus II akan sedikit berubah. Perubahan yang dimaksud adalah sebelum siswa mengerjakan LKS, maka terlebih dahulu setiap kelompok diminta untuk memberikan beberapa contoh masalah seperti yang ada di lembar ahli, tetapi tidak boleh sama dengan yang ada di lembar ahli. Setelah semua kelompok menyampaikan pendapatnya, mereka baru diperbolehkan mengerjakan LKS.

b. Siklus II

1) Perencanaan Seperti halnya pada siklus I tahap perencanaan pada siklus II ini dihasilkan perangkat pembelajaran berupa RPP, Buku Siswa, Buku Guru, dan LKS dengan pokok bahasan Bilangan Pecahan, yang meliputi operasi penjumlahan, pengurangan, perkalian, dan pembagian. Sedangkan instrumen yang digunakan sama dengan pada siklus I, yaitu lembar pengamatan aktivitas siswa, dan guru. Kedua instrumen tersebut sama dengan yang digunakan pada siklus I.

2) Pelaksanaan dan Observasi

Tahap ini merupakan pelaksanaan dari RP yang sudah didesain mengikuti model pembelajaran kooperatif tipe Jigsaw dengan pokok bahasan Bilangan Pecahan.Siklus II ini hanya terdiri dari dua tatap muka.Pada tatap muka pertama membahas operasi penjumlahan dan pengurangan pada bilangan pecahan, sedangkan pada tatap muka kedua membahas operasi perkalian dan pembagian. Setelah dilakukan pengamatan diperoleh data sebagai berikut.

a) Data Aktivitas Siswa

Data aktivitas siswa yang diperoleh pada siklus II diilustrasikan pada tabel berikut.

\begin{tabular}{c|c|c|c|}
\multicolumn{4}{|c}{ Aktivitas Siswa Tiap Kategori Pada Siklus II } \\
\hline Kategori & Frekuensi Rata-rata (\%) Pertemuan Ke & Rata-rata \\
\cline { 2 - 4 } Pengamatan & I & II & $(\%)$ \\
\hline 1 & 12 & 11.286 & 11.643 \\
\hline 2 & 16 & 16,857 & 16,4285 \\
\hline 3 & 4 & 2.429 & 3.214 \\
\hline 4 & 1.333 & 0.857 & 1.095 \\
\hline 5 & 6 & 5 & 5.5 \\
\hline 6 & 19.833 & 17.429 & 18.631 \\
\hline 7 & 11,0855 & 10,9285 & 11,007 \\
\hline 8 & 1.5 & 1.286 & 1.393 \\
\hline 9 & 1.167 & 6.143 & 3.655 \\
\hline 10 & 11,0835 & 10,9285 & 11,007 \\
\hline 11 & 16 & 16,857 & 16,4285 \\
\hline JUMLAH & 100 & 100 & 100 \\
\hline
\end{tabular}

Frekuensi rata-rata aktivitas siswa yang termasuk kategori aktif sebesar $666,25 \%$

b) Data Aktivitas Guru

Aktivitas guru pada siklus II ini sudah sangat baik. Guru tidak mengalami kesulitan, baik untuk mengorganisasikan siswa, membimbing siswa, juga mengatasi siswa yang berprilaku tidak relevan. Selengkapnya perkembangan aktivitas guru dapat dilihat pada tabel berikut.

Tabel 5. Perkembangan Tingkat Kinerja Aktivitas Guru pada siklus I

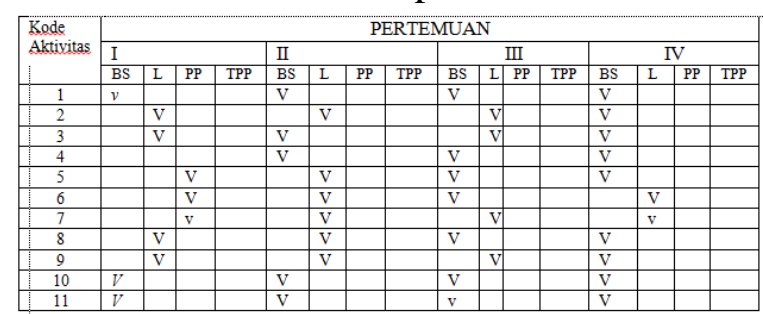

Keterangan :

BS=Baik SEkali

$\mathrm{L}=$ Layak

$\mathrm{PP}=$ Perlu Perbaikan

TPP $=$ Tidak perlu perbaikan

3) Refleksi Dengan memperhatikan hasil pengamatan baik terhadap siswa maupun terhadap guru, diperoleh hal-hal sebagai berikut. Prosentase rata-rata aktivitas yang termasuk kategori partisipasi aktif sebesar 63,488\%. V Prosentase aktivitas mengemukakan pendapat meningkat yaitu dari $1,24 \%$ menjadi 5,5\%. Begitu juga pada kategori yang lain, yang termasuk 
kategori partisipasi aktif. Sedangkan prosentase perilaku yang tidak relevan dan mendengarkan penjelasan teman atau guru menurun.Hal ini menunjukkan perubahan langkah pembelajaran yang digunakan oleh guru cukup efektif dalam memotivasi siswa untuk lebih berani berpendapat.

$\mathrm{V}$ Tingkat kinerja aktivitas guru semakin baik, walaupun masih ada beberapa kekurangan. Misalnya cara mengajukan pertanyaan dan membimbing siswa menyajikan hasil diskusi kelompok. Pada siklus II ini masih ada kelompok yang anggotanya tidak kompak. Walaupun guru sudah berusaha memotivasi mereka, bahwa jika tidak mencoba, maka kita tidak tahu salah benarnya.

\section{B. Pembahasan}

Partisipasi aktif siswa pada refleksi awal sebesar 30\%, pada siklus I 54,309\% dan pada siklus II 63,488\%. Prosentase ini menunjukkan bahwa selama proses pembelajaran terjadi peningkatan partisipasi aktif siswa. Pada siklus I siswa lebih senang mendengarkan, mengerjakan LKS dan membaca buku siswa.Mereka enggan untuk memberikan penjelasan kepada temannya.Ada yang takut salah bahkan ada yang takut temannya menjadi lebih baik nilainya. Kondisi ini dapat dilihat dari prosentase aktivitas bertanya $1,02 \%$, memberi saran $0,29 \%$, mengemukakan pendapat $1,237 \%$, serta mengambil kesimpulan $0,655 \%$.

Aktivitas mengemukakan pendapat, mereka lebih senang menjawab secara bersamaan. Apabila guru meminta satu orang diantara mereka untuk menjawab, mereka memilih diam. Untuk mengatasi hal ini guru cukup baik dalam memotivasi mereka, yaitu dengan cara memberikan penghargaan baikuntuk individu maupun kelompok. Pemberian penghargaan ini sejalan dengan tahapan yang ada pada kooperatif tipe Jigsaw.

Pada siklus II terjadi perubahan yang cukup baik. Hal ini terlihat dari aktivitas bertanya meningkat dari $1,02 \%$ menjadi $3,124 \%$. Prosentase ini mengindikasikan bahwa rasa takut salah dan malu untuk bertanya sudah berkurang. Begitu juga pada aktivitas mengemukakan pendapat, terjadi peningkatan yang cukup tinggi, yaitu dari $1,237 \%$ menjadi $5,5 \%$. Siswa sudah mulai mau berbagi kepada teman-temannya.Bahkan mereka juga sudah berani mengajukan saran atau mengomentari pendapat temannya yang keliru. Hal ini terlihat dari prosentase aktivitas mengajukan saran dari $0,29 \%$ menjadi $1,095 \%$.

Kalau diperhatikan tiap aktivitas, memang peningkatannya tidak seberapa besar.Tetapi kalau dilihat dari pengelompokan partisipasi aktif dan pasif, prosentase tersebut cukup cukup besar.

Meningkatnya prosentase partisipasi aktif siswa sejalan dengan perkembangan tingkat kinerja guru.Hal ini dapat dilihat dari kinerja guru mulai pertemuan ke satu ke pertemuasn lainnya makin baik, sesuai dengan yang didesain dalam RPP.

Respon siswa terhadap materi dalam buku siswa 39,394\% menyatakan sangat senang dan $48,485 \%$ menyatakan senang.Hal ini menunjukkan bahwa buku siswa yang disusun sesuai dengan yang diharapkan siswa.

Respon siswa terhadap LKS 39,394\% menyatakan sangat senang dan $51,515 \%$ menyatakan senang.Hal ini menunjukkan bahwa LKS yang disusun sesuai dengan tuntutan siswa.

Respon siswa terhadap suasana kelas sebanyak $27,273 \%$ menyatakan sangat senang dan $24,242 \%$ menyatakan senang. Jadi pada dasarnya siswa yang menyukai suasana kelas dengan pembelajaran menggunakan model pembelajaran kooperatif tipe Jigsaw adalah sebanyak 51,52\%. Sementara itu yang menyatakan tidak senang sebanyak $45,45 \%$. Prosentase yang senang dengan yang tidak senang terhadap suasana kelas ini tidak begitu besar perbedaannya. Hal ini disebabkan mereka belum terbiasa dengan suasana yang baru.Para siswa terbiasa duduk dengan rapih untuk menyimak penjelasan dari guru. Sedangkan dalam model pembelajaran kooperatif tipe Jigsaw, semua siswa dituntut aktif dalam proses pembelajaran. Baik dalam proses pemahaman konsep maupun dalam presentasi. Hal inilah yang menyebabkan siswa kurang menyenangi suasana seperti itu.

Berkenaan dengan cara guru mengajar, sebanyak $66,667 \%$ menyatakan 
sangat senang dan 30,303\% menyatakan senang. Jadi cara guru mengajar sudah menyenangkan siswa. Hal ini terjadi karena selama proses pembelajaran guru selalu memberikan motivasi positif dan setiap ada siswa yang berhasi, guru selalu memberikan penghargaan. Penghargaan yang diberikan biasanya berupa pujian.Sementara itu apabila ada siswa yang belum berhasil, guru dengan sabar membimbing mereka dengan pertanyaan-pertanyaan yang mengarahkan pada pemahaman konsep tersebut.

Sehubungan dengan materi buku siswa sebanyak 96,97\% menyatakan baru. Sedangkan terhadap LKS sebanyak 90,91\% menyatakan baru, terhadap suasana kelas sebanyak 66,67 menyatakan baru, dan terjhadap suasana mengajar sebanyak $100 \%$ menyatakan baru. Dengan demikian bentuk buku siswa, LKS, suasana kelas dan cara guru mengajar, menurut para siswa termasuk baru. Dengan kondisi seperti itu penulis mengharapkan agar guru matematika di sekolah tersebut, dapat membuat buku siswa atau LKS sendiri.Selama ini LKS yang digunakan di sekolah tersebut adalah LKS yang dibeli dari penerbit. Dengan adanya LKS yang dibuat oleh guru, siswa akan lebih mudah memahami LKS tersebut, karena bahasa yang digunakan dalam LKS buatan guru sudah mereka kenal dengan baik.

Berhubungan dengan minat siswa terhadap model pembelajaran kooperatip tipe Jigsaw sebanyak 93,9\% menyatakan berminat untuk mengikuti pada materi yang lain. Besarnya minat siswa terhadap model pembelajaran kooperatif tipe jigsaw, mengindikasikan bahwa model pembelajaran tersebut perlahan-lahan dapat diterima oleh siswa.Pembelajaran kooperatif tipe Jigsaw menuntut siswa lebih aktif dalam perolehan suatu konsep. Apabila siswa sudah terbiasa aktif dalam perolehan suatu konsep, maka siswa tersebut akan lebih mandiri. Apabila ada guru yang tidak hadir, maka mereka akan terbiasa belajar sendiri baik di kelas maupun di perpustakaan.

\section{Simpulan}

Berdasarkan hasil penelitian dan pembahasan dapat disimpulkan bahwa meningkatkan partisipasi siswa kelas V SDN
Penedapa Kec Poso Pesisir tahun ajaran 2018/2019 dalam pembelajaran matematika melalui model pembelajaran kooperatif tipe Jigsaw dilakukan dengan cara sebagai berikut. a. Mengembangkan RPP yang didesain sesuai dengan langkah-langkah pada model pembelajaran kooperatif tipe Jigsaw. Adapun pelaksanaannya diatur sebagai berikut.

- Pembentukan kelompok asal.

- oPembagian tugas.

- oSiswa yang mendapat tugas sama berkumpul dalam satu kelompok, dan disebut kelompok ahli.

- oMembaca (siswa membaca buku siswa).

- oDiskusi kelompok (pada kelompok ahli).

- oLaporan tim (menjelaskan pada kelompok asal).

- oKuis (mengerjakan LKS).

- oPenghargaantim.

b. Mendesain buku guru. Buku ini merupakan panduan bagi guru untuk membimbing siswa selama proses pembelajaran.

c. Mendesain buku siswa. Buku siswa ini merupakan kumpulan dari lembar ahli yang berisi uraian materi masing-masing topik. Selain buku siswa disusun juga LKS untuk tiap topik.

d. Setelah dilakukan pengamatan terhadap aktivitas siswa, diperoleh rata-rata kadar partisipasi aktif siswa sebesar 54,309\% pada siklus I dan $63,488 \%$ pada siklus II.

e. Respon siswa terhadap KBM dengan model pembelajaran kooperatif tipe Jigsaw positif. Hal ini dapat dilihat dari prosentase siswa yang merasa sangat senang dan senang terhadap materi sebanyak $87,87 \%$, sangat senang dan senang terhadap LKS sebanyak $80,9 \%$, sangat senang dan senang terhadap cara guru mengajar sebanyak $96,97 \%$, sangat senang dan senang terhadap kuis yang

\section{Saran}

1. Bagi siswa

Penelitian Tindakan kelas ini bermanfaat untuk meningkatkan hasil belajarnya pun dapat meningkatkan motivasi belajar 
2. Bagi Guru

Untuk dijadikan acuan atau gambaran pembelajaran sehingga dapat dijadikan pedoman dalam pelaksanaan pembelajaran

3. Bagi Satuan Pendidikan

Hasil penelitian tidakan kelas ini dapat dijadikan masukan atau input untuk dapat dipertimbangkan kebijakan dalam menetapkan kebijakan baru untuk peningkatan mutu pendidikan disekolah

\section{DAFTARPUSTAKA}

Arends, R.L (1997). Classroom Instructional and Management. Central Connecticut State University : The Mc.Graw-Hill Companies, Inc.

Depdiknas dirjen Dikti (2005).Pedoman Penyusunan Usulan dan Laporan Penelitian Tindakan kelas (Classroom Action Research).Jakarta : Direktorat Pembinaan Pendidikan Tenaga Kependidikan dan ketenagaan perguruan Tinggi.

Depdiknas (2003).Kurikulum 2004 Standar Kompetensi Mata Pelajaran Matematika Sekolah Menengah Pertama dan Madrasah Tsanawiyah.Jakarta : Depdiknas.

Djumanta, Wahyudin (2005). Mari Memahami Konsep Matematika untuk Kelas VII. Bandung: Grafindo Media Pratama.

Lince, Ranak (2006). Pengembangan Perangkat Pembelajaran dengan pendekatan Struktural Pada Pokok Bahasan Persamaan Garis di Kelas IISMP.Makalah Komprehensif. Surabaya : Program Pascasarjana Universitas Negeri Surabaya.

Muslimin dkk (2008).Pembelajaran Kooperatif. Buku Ajar Pengembangan Guru Sekolah Menengah.Surabaya : Pusat Sains dan Matematika Sekolah UNESA.

Nur, Muhammad (2007). Pembelajaran Kooperatif. Surabaya : Pusat Sains dan Matematika Sekolah UNESA.

Sudirman (2007). Interaksi dan Motivasi Belajar Mengajar.Jakarta : Rajawali 